\title{
Characterisation of PPNG and non-PPNG Neisseria gonorrhoeae isolates from Singapore
}

\author{
C L Poh, J C Ocampo, E H Sng, S M Bygdeman
}

\begin{abstract}
Objective-To characterise Neisseria gonorrhoeae isolates from Singapore.

Design-Characterisation of Neisseria gonorrhoeae isolates by auxotyping, serological analysis and plasmid profile analysis.

Specimens-Sixty randomly collected isolates from 41 symptomatic, untreated males and 19 female prostitutes were studied.

Results-Auxotyping of 25 PPNG and 35 nonPPNG strains showed that the Pro- auxotype was prevalent among both PPNG (56\%) and non-PPNG (42.5\%) strains. Prototrophic strains comprised $28 \%$ of PPNG and $32.5 \%$ of non-PPNG strains respectively. Serovar analysis showed that with the exception of seven serogroup WI strains, the majority belonged to serogroup WII/III. Serovar Aedih was predominant among both serogroup WI PPNG $(80 \%)$ and non-PPNG $(100 \%)$ strains. Serogroup WII/III PPNG strains were represented by nine serovars with the predominant serovars being Bacjk $(28 \%)$ and Bcgjk (16\%). Eleven serovars were identified in the WII/III non-PPNG strains and the major serovars were Bajk (20\%), Bacjk (17\%), Back $(11 \cdot 4 \%)$ and Beghjk (11.4\%). Analysis of the 25 PPNG strains showed that 16 of them carried the $4.4 \mathrm{MDa}$ (Asian type) resistance plasmid and nine strains harboured the $4.4 \mathrm{MDa}$ plasmid in conjunction with the 24.5 MDa transfer plasmid. The cryptic plasmid of $2 \cdot 6 \mathrm{MDa}$ was present in 27 of the 35 non-PPNG strains. Five of the non-PPNG strains harbouring the cryptic plasmid also contained the 24.5 MDa trans-
\end{abstract}

Department of Microbiology, Faculty of Medicine, National University of Singapore, Lower Kent Ridge Road, Singapore 0511

C L Poh, J C Ocampo

Pathology Department, Singapore General Hospital Outram Road, Singapore 0316

E H Sng

Department of Clinical Bacteriology, Huddinge University Hospital, Karolinska Institute, Stockholm, Sweden

S M Bygdeman fer plasmid. The plasmid combination of $2 \cdot 6+$ $7 \cdot 8+24 \cdot 5 \mathrm{MDa}$ was detected in three nonPPNG strains.

Conclusion-The combination of epidemiological methods used in this study indicated the heterogeneity of $\boldsymbol{N}$ gonorrhoeae strains in Singapore. A total of 16 different combinations of auxotype, plasmid profile and serovar were seen in the 25 PPNG strains compared with 24 such combinations in the 35 non-PPNG strains. Such sensitive differentiation would otherwise not be possible using either auxotype-serovar (A/S) or auxotype-plasmid analysis.

\section{Introduction}

Monitoring the international dissemination of gonococcal infections will require epidemiological characterisation of Neisseria gonorrhoeae isolates from various countries. Epidemiological data regarding the phenotypes of $N$ gonorrhoeae are now available from countries such as Africa, Britain, Canada, Greece, Holland, Norway, Spain, Sweden and the United States. ${ }^{1-9}$ Strains from these countries have been extensively characterised by auxotyping, serological classification and plasmid profile analysis. With the exception of a previous study by Odugbemi et al $(1983)^{13}$ of strains from Korea, few strains from South East Asia have been characterised to such detail. ${ }^{310}$ As countries in South East Asia form important foci for the transmission of PPNG (Asian ${ }^{+}$ strains) to the rest of the world, it is essential to characterise the gonococcal populations from South East Asian countries in terms of the variables that have been used to characterise strains from the rest of the world.

The present study was undertaken to define the $N$ gonorrhoeae population in Singapore by auxotyping, serological classification and plasmid profile analysis.

Materials and methods

Gonococcal strains

We studied $60 N$ gonorrhoeae strains randomly isolated over 6 months in 1984 from both male and female patients who attended the Middle Road Hospital as outpatients. Twenty seven of the isolates 
were from symptomatic, untreated male patients with urethritis while the rest were from female prostitutes. All isolates were confirmed as $N$ gonorrhoeae by colony morphology, Gram stain, oxidase reaction and acid production from glucose but not maltose, sucrose, lactose or fructose. Purified stock cultures were maintained in Trypticase soy broth (BBL Microbiology Systems, Cockeysville, Md) containing $20 \%$ glycerol and stored at $-70^{\circ} \mathrm{C}$. Isolates were subcultured on modified ThayerMartin agar (MTM, BBL) and incubated at $36^{\circ} \mathrm{C}$ with a $5 \% \mathrm{CO}_{2}$ atmosphere in a humidified incubator for 20 hours. The isolates were tested for betalactamase production by means of the chromogenic cephalosporin substrate, Nitrocefin (Oxoid).

\section{Serological characterisation}

The strains were serologically characterised by coagglutination using monoclonal antibodies to protein I as described by Bygdeman et al. ${ }^{10}$ Isolates were identified as belonging to serogroups designated WI or WII/WIII. Serogroups were subdivided into different serovars using monoclonal antibodies specific for protein IA or IB. For the identification of WI strains, seven protein IA-specific monoclonal antibodies were used. Protein IA-specific antibodies were designated as follows: $4 \mathrm{~A} 12, \mathrm{~b} ; 2 \mathrm{~F} 12, \mathrm{~d} ; 6 \mathrm{G} 9, \mathrm{f}$; $6 \mathrm{D} 9, \mathrm{~g} ; 5 \mathrm{D} 1, \mathrm{~h} ; 5 \mathrm{G} 9, \mathrm{i}$; and $5 \mathrm{C} 2, \mathrm{k}$. Identification of WII and WIII strains was achieved by using eight protein IB-specific monoclonal antibodies. Protein IB-specific antibodies were designated as follows: 3C8,a; 1F5,b; 2D6,c; 2H7,e; 2G2,g; 2D4,h; 3B10,j; and $2 \mathrm{H} 1, \mathrm{k}$. All the designations of the WI serovars begin with an A (protein IA) and the designations of the WII and WIII serovars begin with B (protein IB). All isolates were typed at the Karolinska Institute.

\section{Auxotyping}

Auxotyping was performed as described by Catlin. ${ }^{11}$ Strains were tested for their requirement for proline $\left(\mathrm{Pro}^{-}\right)$, arginine $\left(\mathrm{Arg}^{-}\right)$, methionine $\left(\mathrm{Met}^{-}\right)$, hypoxanthine $\left(\mathrm{Hyx}^{-}\right)$, and uracil $\left(\mathrm{Ura}^{-}\right)$or for combinations of these requirements. Strains with no specific requirements are regarded as prototrophic (Proto).

\section{Plasmid profile analysis}

Plasmids were identified following extraction based on a procedure described by Kado and $\mathrm{Liu}^{12}$. Control strains with plasmids of known molecular weights were included as size markers in agarose gel electrophoresis.

\section{Results}

\section{Auxotypes}

Of the 60 isolates examined, 25 were PPNG strains. The 25 PPNG strains could be resolved into four auxotypes and the 35 non-PPNG strains were differentiated into five auxotypes. The $\mathrm{Pro}^{-}$auxotype predominated in both PPNG (in 14,56\%) and nonPPNG strains (in 17, 42.5\%), followed by prototrophic (Zero auxotype) strains (in 7 PPNG, 28\% and in 13 non-PPNG, 32.5\%). The Pro- $\mathrm{Arg}^{-}$ auxotype was represented by three PPNG and three non-PPNG strains.

\section{Serogroups and serovars}

Most of the PPNG (20, 80\%) and non-PPNG (33, $94.3 \%$ ) strains belonged to the WII/III serogroups. Strains belonging to the WI serogroup was further differentiated into two serovars and the WII/III serogroup was represented by 11 serovars. The serovar Aedih predominated amongst the WI serogroup of both PPNG and non-PPNG strains. Only one other strain typed as serovar Aed was found in the WI serogroup. The predominant serovars identified amongst the WII serogroup strains were Bacjk $(22 \cdot 4 \%)$, Bajk (17.2\%), Bagjk (12\%) and Beghjk $(10 \cdot 3 \%)$. The PPNG strains could be resolved into 11 different serovars, four auxotypes but 14 different auxotype/serovar classes. The 35 non-PPNG strains belonged to 12 different serovars, five auxotypes and were subtyped into 22 different auxotype/serovar classes.

\section{Plasmid profiles}

The 35 non-PPNG strains were divided into three main groups based on the plasmid profiles generated. Two profiles were observed amongst the 25 PPNG isolates. The cryptic plasmid of $2.6 \mathrm{MDa}$ was present in both PPNG and non-PPNG isolates. Non-PPNG strains $(27,77 \cdot 1 \%$ of the total non-producing) with plasmid profile I carried only $2.6 \mathrm{MDa}$ cryptic plasmid whilst five strains $(14.3 \%$ of total nonPPNG) had the conjugative plasmid of $24.5 \mathrm{MDa}$ in conjunction with the $2.6 \mathrm{MDa}$ plasmid. Non-PPNG strains $(3,8.6 \%)$ displaying plasmid profile III were found to carry three plasmids of M.wt. $2 \cdot 6 \mathrm{MDa}, 7 \cdot 8$ $\mathrm{MDa}$ and 24.5 MDa (table 1).

Two plasmid profiles were evident amongst the 25 PPNG strains. Group I PPNG strains $(16,64 \%$ of the total PPNG) carried the $2.6 \mathrm{MDa}$ plasmid and the $4.4 \mathrm{MDa}$ penicillinase plasmid (Asian type). Group II PPNG strains $(9,36 \%)$ harboured the 24.5

Table 1 Plasmid profile of PPNG and non-PPNG strains

\begin{tabular}{|c|c|c|c|c|}
\hline \multicolumn{2}{|c|}{ Non-PPNG strains ( $n=35$ ) } & \multicolumn{3}{|c|}{$P P N G$ strains $(n=25)$} \\
\hline $\begin{array}{l}\text { Plasmid profile } \\
(M . W t . \text { in } M D a)\end{array}$ & $\begin{array}{l}\text { No of } \\
\text { strains }\end{array}$ & $\begin{array}{l}\text { Pla } \\
\text { M }\end{array}$ & $\begin{array}{l}\text { ssmid profile } \\
\text { 1. Wt. in } M D a)\end{array}$ & $\begin{array}{l}\text { No of } \\
\text { strains }\end{array}$ \\
\hline $\begin{aligned} & \text { I } 2 \cdot 6 \\
& \text { II } 2 \cdot 6+24 \cdot 5 \\
& \text { III } 2 \cdot 6+7 \cdot 8+24 \cdot 5 \\
&\end{aligned}$ & $\begin{array}{r}27 \\
5 \\
3\end{array}$ & I & $\begin{array}{l}2 \cdot 6+4 \cdot 4 \\
2 \cdot 6+4 \cdot 4+24 \cdot 5\end{array}$ & $\begin{array}{r}16 \\
9\end{array}$ \\
\hline
\end{tabular}

$\mathrm{MDa}=$ megadaltons. 
Table 2 Relation between plasmid profile, auxotype, serogroup and serovar of 35 non-PPNG strains

\begin{tabular}{|c|c|c|c|c|}
\hline Plasmid profile & Auxotype & Serogroup & Serovar & No of strains \\
\hline $\begin{array}{l}2 \cdot 6 \\
2 \cdot 6 \\
2 \cdot 6 \\
2 \cdot 6 \\
2 \cdot 6 \\
2 \cdot 6 \\
2 \cdot 6 \\
2 \cdot 6 \\
2 \cdot 6 \\
2 \cdot 6 \\
2 \cdot 6 \\
2 \cdot 6 \\
2 \cdot 6 \\
2 \cdot 6 \\
2 \cdot 6 \\
2 \cdot 6 \\
2 \cdot 6+24 \cdot 5 \\
2 \cdot 6+24 \cdot 5 \\
2 \cdot 6+24 \cdot 5 \\
2 \cdot 6+24 \cdot 5 \\
2 \cdot 6+24 \cdot 5 \\
2 \cdot 6+7 \cdot 8+24 \cdot 5 \\
2 \cdot 6+7 \cdot 8+24 \cdot 5 \\
2 \cdot 6+7 \cdot 8+24 \cdot 5\end{array}$ & $\begin{array}{l}\text { Proto } \\
\text { Pro- }^{-} \mathrm{Met}^{-} \\
\text {Pro- }^{-} \\
\text {Pro- }^{-} \\
\text {Pro }^{-} \\
\text {Pro }^{-} \\
\text {Pro- } \\
\text { Pro- } \\
\text { Pro- } \\
\text { Pro-Hyx- } \\
\text { Pro-Arg- } \\
\text { Proto } \\
\text { Proto } \\
\text { Proto } \\
\text { Proto } \\
\text { Proto } \\
\text { Pro-Arg- } \\
\text { Proto } \\
\text { Proto } \\
\text { Proto } \\
\text { Proto } \\
\text { Pro- } \\
\text { Pro-Arg- } \\
\text { Proto }\end{array}$ & $\begin{array}{l}\text { WI } \\
\text { WI } \\
\text { WII/III } \\
\text { WII/III } \\
\text { WII/III } \\
\text { WII/III } \\
\text { WII/III } \\
\text { WII/III } \\
\text { WII/III } \\
\text { WII/III } \\
\text { WII/III } \\
\text { WII/III } \\
\text { WII/III } \\
\text { WII/III } \\
\text { WII/III } \\
\text { WII/III } \\
\text { WII/III } \\
\text { WII/III } \\
\text { WII/III } \\
\text { WII/III } \\
\text { WII/III } \\
\text { WII/III } \\
\text { WIIIII } \\
\text { WII/III }\end{array}$ & $\begin{array}{l}\text { Aedih } \\
\text { Aedih } \\
\text { Bak } \\
\text { Back } \\
\text { Bajk } \\
\text { Bcgk } \\
\text { Bacjk } \\
\text { Bcgik } \\
\text { Beghjk } \\
\text { Bacjk } \\
\text { Bacjk } \\
\text { Bak } \\
\text { Back } \\
\text { Bajk } \\
\text { Bhk } \\
\text { Beghjk } \\
\text { Bajk } \\
\text { Bajk } \\
\text { Bck } \\
\text { Bcegk } \\
\text { Bcegjk } \\
\text { Bajk } \\
\text { Bcgjk } \\
\text { Bcgk }\end{array}$ & $\begin{array}{l}1 \\
1 \\
1 \\
3 \\
3 \\
2 \\
4 \\
2 \\
1 \\
1 \\
1 \\
1 \\
1 \\
1 \\
1 \\
3 \\
1 \\
1 \\
1 \\
1 \\
1 \\
1 \\
1 \\
1\end{array}$ \\
\hline
\end{tabular}

MDa conjugative plasmid in addition to the $2 \cdot 6 \mathrm{MDa}$ and $4.4 \mathrm{MDa}$ plasmids. The 3.2 $\mathrm{MDa}$ (African type) penicillinase plasmid was not detected in both PPNG and non-PPNG.

Relation between auxotypes, serogroups, serovars and plasmid profiles

Analysis of non-PPNG strains

Table 2 presents the relation between auxotypes, serogroups, serovars and plasmid profiles of the 35 non-PPNG strains tested. Majority $(87.5 \%)$ of the strains carrying the $2.6 \mathrm{MDa}$ cryptic plasmid belonged to the WII/III serogroup. Seven of these were of auxotype $\mathrm{Pro}^{-}$whilst five were prototrophic (non-requiring). Some strains with identical plasmid profile, auxotype and serogroup were distinguishable only by their serovars. Seven serovars were observed amongst the $\mathrm{Pro}^{-}$, WII/III serogroup strains that carried the $2.6 \mathrm{MDa}$ plasmid. Similarly, five Prototrophic WII/III serogroup strains harbouring the 2.6 MDa plasmid were found to be comprised of five serovars. Two strains that had identical plasmid profile (2.6 MDa), serogroup (WI) and serovar (Aedih) were found to be of different auxotypes. This was similarly observed for two other strains of serogroup WII/III, serovar Bacjk that harboured the same $2.6 \mathrm{MDa}$ plasmid.

Of the five strains harbouring the $2.6 \mathrm{MDa}$ cryptic plasmid and the $24.5 \mathrm{MDa}$ transfer plasmid, four were prototrophic (non-requiring) and one required proline and arginine for growth. The four wild type strains could only be differentiated by their serovar differences. Two serogroup WII/III strains (of serovar Bajk) carrying the $2.6 \mathrm{MDa}$ and $7.8 \mathrm{MDa}$ plasmids were found to be differentiated only by their auxotypes. Three serogroup WII/III strains har-

Table 3 Relation between plasmid profile, auxotype, serogroup and serovar of 25 PPNG strains

\begin{tabular}{|c|c|c|c|c|}
\hline Plasmid profile & Auxotype & Serogroup & Serovar & No of strains \\
\hline $\begin{array}{l}2 \cdot 6+4 \cdot 4 \\
2 \cdot 6+4 \cdot 4 \\
2 \cdot 6+4 \cdot 4 \\
2 \cdot 6+4 \cdot 4 \\
2 \cdot 6+4 \cdot 4 \\
2 \cdot 6+4 \cdot 4 \\
2 \cdot 6+4 \cdot 4 \\
2 \cdot 6+4 \cdot 4 \\
2 \cdot 6+4 \cdot 4 \\
2 \cdot 6+4 \cdot 4 \\
2 \cdot 6+4 \cdot 4+24 \cdot 5 \\
2 \cdot 6+4 \cdot 4+24 \cdot 5 \\
2 \cdot 6+4 \cdot 4+24 \cdot 5 \\
2 \cdot 6+4 \cdot 4+24 \cdot 5 \\
2 \cdot 6+4 \cdot 4+24 \cdot 5 \\
2 \cdot 6+4 \cdot 4+24 \cdot 5\end{array}$ & $\begin{array}{l}\text { Pro }^{-} \\
\text {Pro } \\
\text { Pro- } \\
\text { Pro- } \\
\text { Pro- }^{-} \\
\text {Pro }^{-} \\
{\text {Pro- } \text { Met }^{-}}^{-} \\
\text {Pro- Arg }^{-} \\
\text {Pro- Arg } \\
\text { Proto } \\
\text { Pro- } \\
\text { Proto } \\
\text { Pro-Arg- } \\
\text { Proto } \\
\text { Proto } \\
\text { Proto }\end{array}$ & $\begin{array}{l}\text { WI } \\
\text { WII/III } \\
\text { WII/III } \\
\text { WII/III } \\
\text { WII/III } \\
\text { WII/III } \\
\text { WII/III } \\
\text { WII/III } \\
\text { WII/III } \\
\text { WII/III } \\
\text { WI } \\
\text { WI } \\
\text { WII/III } \\
\text { WII/III } \\
\text { WII/III } \\
\text { WII/III }\end{array}$ & $\begin{array}{l}\text { Aed } \\
\text { Bck } \\
\text { Bajk } \\
\text { Bacjk } \\
\text { Bcgjk } \\
\text { Beghjk } \\
\text { Bcgjk } \\
\text { Bcgk } \\
\text { Bcegjk } \\
\text { Bacjk } \\
\text { Aedih } \\
\text { Aedih } \\
\text { Bcegik } \\
\text { Bak } \\
\text { Back } \\
\text { Bacjk }\end{array}$ & $\begin{array}{l}1 \\
1 \\
2 \\
4 \\
3 \\
1 \\
1 \\
1 \\
1 \\
1 \\
1 \\
3 \\
1 \\
1 \\
1 \\
1 \\
2\end{array}$ \\
\hline
\end{tabular}


bouring the $7 \cdot 8 \mathrm{MDa}$ plasmid in conjunction with the 2.6 MDa and 24.5 MDa plasmids were represented by three auxotypes and serovars.

\section{Analysis of PPNG strains}

Of the 16 PPNG strains harbouring the $2.6 \mathrm{MDa}$ and the $4.4 \mathrm{MDa}$ (penicillinase) plasmids, only one strain belonged to serogroup WI. The 15 WII/III serogroup strains could be further differentiated by auxotype and serovar differences. These strains were represented by five auxotypes and seven serovars (table 3).

The nine PPNG strains carrying the $2.6 \mathrm{MDa}, 4.4$ $\mathrm{MDa}$ (penicillinase) and $24.5 \mathrm{MDa}$ plasmids were distributed into two serogroups, three auxotypes and five serovars. Of the four serogroup WI strains exhibiting the same plasmid profile and serovar pattern, one was found to be prototrophic (nonrequiring) whilst the other three were $\mathrm{Pro}^{-}$. Serovar was the only notable difference observed amongst four strains displaying the same serogroup (WII/ III), plasmid profile $(2 \cdot 6,4 \cdot 4,24.5)$ and auxotype (Proto).

\section{Discussion}

Phenotypic characterisation of $\mathrm{Ngonorrhoeae}$ isolates by auxotype, plasmid profile and serovar analysis has provided accurate definition of gonococcal populations. Epidemiological data gathered using this combined approach readily presents a baseline definition of gonococcal strains circulating in any community. The present study provides a detailed characterisation of $N$ gonorrhoeae strains isolated from Singapore in 1984 and the data will be useful for local prospective study of gonococcal infection and for monitoring spread of these strains to other countries.

Characterisation of both PPNG and non-PPNG strains on the basis of auxotypes, plasmid profiles and serovars indicated the heterogeneity of strains comprising each group. The 25 PPNG strains were separated into 16 different combinations whilst 24 different classes were seen amongst the 35 non-PPNG strains. Conclusions drawn regarding the diversity of our local gonococcal populations would have been quite different if we had relied on either auxotype and plasmid profile analysis or auxotype and serovar classification.

Our results extend some previous studies ${ }^{31013}$ regarding the distribution of auxotypes, serogroups, serovars and plasmid profiles. The $\mathrm{Pro}^{-}$and prototrophic (proto, non-requiring) strains were seen as the predominant nutritional types amongst both PPNG (Pro-, 52\%; Proto, 24\%) and nonPPNG (Pro-, $48.5 \%$; Proto, $37 \cdot 1 \%$ ) strains. This observation differed from an earlier study ${ }^{10}$ which showed prototrophic and $\mathrm{Pro}^{-}$auxotype as the preponderant nutritional groups amongst PPNG and
non-PPNG strains respectively. In the present study, $\mathrm{Pro}^{-}$strains were predominant amongst both PPNG and non-PPNG strains.

With the exception of five serogroup WI strains, the rest (55 strains) belonged to the WII/III serogroup. The serovar Aedih dominated among WI PPNG and WI non-PPNG strains. Our results agree with previous observations ${ }^{10}$ that serovar Aedih predominates amongst the WI serogroup strains from South East Asia. As our sample size of serogroup WI strains was small, we did not come across unusual serovars such as Aed, Ad, Afe and Af serovars as was reported earlier ${ }^{3}$. Eleven different serovars were observed among the WII/III nonPPNG strains. Serovars Bajk (20\%), Bacjk (17\%), Back $(11.4 \%)$ and Beghjk $(11.4 \%)$ were the major serovars observed. WII/III PPNG strains were represented by nine serovars and the predominant serovars were Bacjk (28\%) and Bcgjk (16\%).

The 2.6 MDa cryptic plasmid was found to be present in all the 60 strains examined in this study. It is interesting to note the presence of the $7.8 \mathrm{MDa}$ cryptic plasmid in three non-PPNG strains. Restriction digests of plasmid DNA from these three strains with HinfI and AvaII/HinfI produced identical profiles to the $2.6 \mathrm{MDa}$ plasmid DNA similarly digested. The data suggested that the $7 \cdot 8 \mathrm{MDa}$ plasmids are identical to the $2.6 \mathrm{MDa}$ plasmid and are concatemers of the $2.6 \mathrm{MDa}$ plasmid as described previously.$^{14}$ All 35 non-PPNG strains were found to carry the $2.6 \mathrm{MDa}$ cryptic plasmid either alone $(45.6 \%)$ or in conjunction with the $24.5 \mathrm{MDa}$ transfer plasmid $(22.9 \%)$. The PPNG strains $(41.6 \%$ of total) were found to harbour the Asian type resistance plasmid ( $4.4 \mathrm{MDa})$ either in conjunction with the $2.6 \mathrm{MDa}$ plasmid or the $24.5 \mathrm{MDa}$ transfer plasmid plus the $2 \cdot 6 \mathrm{MDa}$ plasmid.

Strains carrying the $4.4 \mathrm{MDa} B$-lactamase plasmid in conjunction with the $2.6 \mathrm{MDa}$ plasmid were mainly $\mathrm{Pro}^{-}$whilst those carrying the $24.5 \mathrm{MDa}$ plasmids were mainly wild-type strains. Diversity of serovars was observed among Pro $^{-}$strains containing both $2.6 \mathrm{MDa}$ and $4.4 \mathrm{MDa}$ plasmids. This was similarly observed among wild-type strains carrying the $24.5 \mathrm{MDa}$ transfer plasmid in conjunction with the $2.6 \mathrm{MDa}$ and $4.4 \mathrm{MDa}$ plasmids. The presence of the same plasmid combinations $(2.6 \mathrm{MDa}+4.4$ $\mathrm{MDa}+24.5 \mathrm{MDa}$ ) in four Proto strains that exhibit serovar diversity suggests that the transfer of these plasmids by either conjugation or transformation has played an important role in their spread. No PPNG isolates was found to carry the $3 \cdot 2 \mathrm{MDa}$ "African" B-lactamase plasmid or the $3.05 \mathrm{MDa}$ "Toronto" plasmid. The $25 \cdot 2 \mathrm{MDa}$ tet $\mathrm{M}$-conjugative plasmid was similarly not detected.

The combined approach of applying auxotyping, plasmid profile analysis and serological classification has enabled us to characterise the gonococcal popula- 
tion in Singapore. The data clearly show that $N$ gonorrhoeae strains isolated here differed from those that were endogenous in Canada, ${ }^{3}$ Africa ${ }^{1}$ and Greece. ${ }^{4}$ Strains isolated from these three regions tend to belong to serogroup WI whereas serogroup WII/III strains were predominant in our study. Predominant auxotypes such as $\mathrm{AHU}^{-}$and $\mathrm{PCU}^{-}$ typical of Canadian isolates were not detected in our samples.

Characteristic biological differences found between gonococcal strains isolated from different geographical areas of the world are useful for tracing exportation of strains. Such differences have also led to a better assessment of the efficacy of antibiotic treatment as strains could be readily differentiated prior to and after treatment. We found in this study serovar diversity has been the most useful biological difference for strain differentiation.

Address for correspondence: Dr C L Poh, Department of Microbiology, National University of Singapore, Lower Kent Ridge Road, Singapore 0511.

1 Odugbemi TO, Brown ST, Biddle J, et al. Plasmid profile, serogrouping of Neisseria gonorrhoeae isolates from Africa. Br JVenereal Dis 1983;59:41-3.

2 Woodford N, Bindayna KM, Easmon CSF, Ison CA. Associations between serotype and susceptibility to antibiotics of Neisseria gonorrhoeae. Genitourin Med 1989;65:86-91.
3 Dillon JR, Bygdeman SM, Sandström EG. Serological ecology of Neisseria gonorrhoeae (PPNG and non-PPNG) strains: Canadian perspective. Genitourin Med 1987;63:160-8.

4 Tzanakaki G, Mavrommati L, Tzelepi E, et al. Serological classification in relation to auxotypes, plasmid contents, and susceptibilities to antimicrobials of PPNG and non-PPNG strains isolated in Greece. Genitourin Med 1989;65:171-6.

5 Ansink-Schipper MC, Bygdeman SM, Van Klingeren B, et al. Serovars, auxotypes and plasmid contents of PPNG strains from outbreaks in Amsterdam. Genitourin Med 1987;63: 157-59.

6 Falk ES, Bjorvatn B, Kristiansen BE, et al. Some phenotypic and genotypic characteristics of prevailing gonococcal strains in northern Norway. Genitourin Med 1986;62:9-14.

7 Palomares JC, Lozano MC, Perca EJ. Antibiotic resistance, plasmid profile, auxotypes and serovars of Neisseria gonorrhoeae strains isolated in Sevilla (Spain). Genitourin Med 1990;66:87-90.

8 Danielsson D, Bygdeman S, Kallings I. Epidemiology of gonorrhoeae: serogroup, antibiotic susceptibility and auxotype patterns of consecutive gonococcal isolates from ten different areas in Sweden. Scand J Infect Dis 1983;15:33-42.

9 Hook EW III, Judson FN, Handsfield HH, et al. Auxotype/ serovar diversity and antimicrobial resistance of Neisseria gonorrhoeae in two mid-sized American cities. Sex Transm Dis 1987;14:141-6.

10 Bygdeman S. Polyclonal and monoclonal antibodies applied to the epidemiology of gonococcal infection. In: Young $\mathrm{H}$, McMillan A, eds. Immunological Diagnosis of Sexually Transmitted Diseases. New York: Marcel Decker, 1987:117-65.

11 Catlin BW. Nutritional profiles of Neisseria gonorrhoeae, Neisseria meningitidis and Neisseria lactamica in chemically defined media and the use of growth requirements for gonococcal typing. J Infect Dis 1973;128:178-94.

12 Kado CI, Liu ST. Rapid procedure for detection and isolation of large and small plasmids. $J$ Bacteriol 1981;145:1365-73.

13 Odugbemi TO, Whittington WL, DeWitt W, et al. Epidemiological characterisation of Neisseria gonorrhoeae isolates from the Far East. Br J Venereal Dis 1983;59:285-8.

14 Johnson SR, Anderson BE, Biddle JW, et al. Characterization of concatemeric plasmids of Neisseria gonorrhoeae. Infect Immun 1983;40:843-6.

Accepted for publication 6 June 1991 